\title{
Review on common buckwheat (Fagopyrum esculentum Moench): A potent Himalayan crop
}

\author{
Kuldip Chandra Verma*, Amit Singh Rana, Nidhi Joshi and Dheeraj Bhatt \\ Department of Biochemistry, College of Basic Sciences and Humanities, Govind Ballabh Pant University of Agriculture and Technology, \\ Pantnagar (U. S. Nagar)-263145, Uttarakhand, India.
}

\section{Article Info}

Article history

Received 11 August 2020

Revised 27 September 2020

Accepted 29 September 2020

Published online 30 December 2020

\section{Keywords}

Antioxidant activity

Buckwheat

Chemical composition

Nutritional value

Protein

Resistant starch

Rutin

Fagopyrum esculentum

\begin{abstract}
Buckwheat (Fagopyrum esculentum Moench), is the major traditional crop in hilly regions, having high nutritional value, having ability to grow in adverse climatic conditions and requires low cultivating cost. Buckwheat comes with a lot of promise as substitute staple crop as it has all the essential requirements, found in common cultivated crops. Buckwheat having high protein content, a well balanced amino acid composition, essential fats (linoleic, linolenic, etc.), important phenolic compounds (flavonoids: rutin, flavanols, etc.) and other prophylactic compounds, viz., fagopyrins, thiamin-binding proteins, etc. Nowadays, buckwheat cultivation area all over the world is continuously decreasing due to some limitations in its cultivation. In India, Himalayan states are home of the buckwheat production, where it mainly used in various food preparations and for therapeutic remedies like constipation, high cholesterol, high blood pressure, and cardiovascular problems, etc. This review includes plants characteristic, cultivation and detailed chemical composition of buckwheat with its utilities. The review is based on the chemical composition of buckwheat, importance and applications of its metabolites and limitations of buckwheat cultivation in present scenario.
\end{abstract}

\section{Introduction}

Faced with acute problem of protein energy malnutrition in the vast prevailing, vulnerable population of our country, the content and quality of pseudocereal proteins become a pertinent point of consideration (Loch et al., 2010; Radics and Mikohazi, 2010). Buckwheat (Fagopyrum esculentum Moench) is a pseudocereal that has been long being neglected due to competition with cereals like wheat, etc. as it resembles cereals in its composition and use. It was a very popular food during the $17^{\text {th }}-19^{\text {th }}$ century; however in the $20^{\text {th }}$ century, wheat took over (Campbell, 1997).

\subsection{Plant Botany}

Buckwheat belongs to the family Polygonaceae, is an annual herb, up to $1 \mathrm{~m}$ tall, branched, glabrous. This species is dimorphic, flowers are perfect but incomplete. In place of petals, calyx have five petals like sepals of white, pink or dark pink colors. The fruit of buckwheat is a triangular achene. Fruit is more than $5 \mathrm{~mm}$

Corresponding author: Dr. Kuldip Chandra Verma Assistant Professor, Department of Biochemistry, College of Basic Sciences and Humanities, Govind Ballabh Pant University of Agriculture and Technology, Pantnagar (U. S. Nagar)-263145, Uttarakhand, India. E-mail: kcbiochem@gmail.com

Tel.: +91-8968970844

Copyright (c) 2020 Ukaaz Publications. All rights reserved.

Email: ukaaz@yahoo.com; Website: www.ukaazpublications.com long, more than double the size of perianths, triquetrous, usually brown/blackish brown color lucid structure (Figure 1). It structurally resembles the cereal grains. The hull (pericarp, fruit coat), the outer layer of the achene, has a hard fibrous structure that is usually dark brown or black in colour. Removal of hulls by impact dehulling releases whole groats. The outer part of the dehulled achene is the seed coat, a fibrous layer composed of cells with thickened cell walls and remnants of the nucellus (perisperm). The aleurone, the outermost layer of cells in the endosperm, is a single layer of small cells with thick cell walls. Central endosperm cells have thin cell walls and are packed with starch granules (Joshi and Paroda, 1991).

The weight of 1000 seeds is about $24 \mathrm{~g}$ and can vary from varietyto-variety. The seeds are grown best in warm soil and seeds germinate in about 3-4 days. The flower is heart shaped with white petals and have hollow stem, this flowering begins 3 weeks after planting (Figure 2), but tapers off as the plant grows. It takes 10 days to form full sized seed after the flower is pollinated, though it takes another 2-3 weeks for the seed to attain maturity. Plant height and maturity time depends on the time of the year of planting, for example: early in the summer and with good fertility plant will usually be $1 \mathrm{~m}$ tall and will take around 11-12 weeks to mature. If planted at the end of July, the plant will mature in 9-10 weeks (Ahmed et al., 2014). 


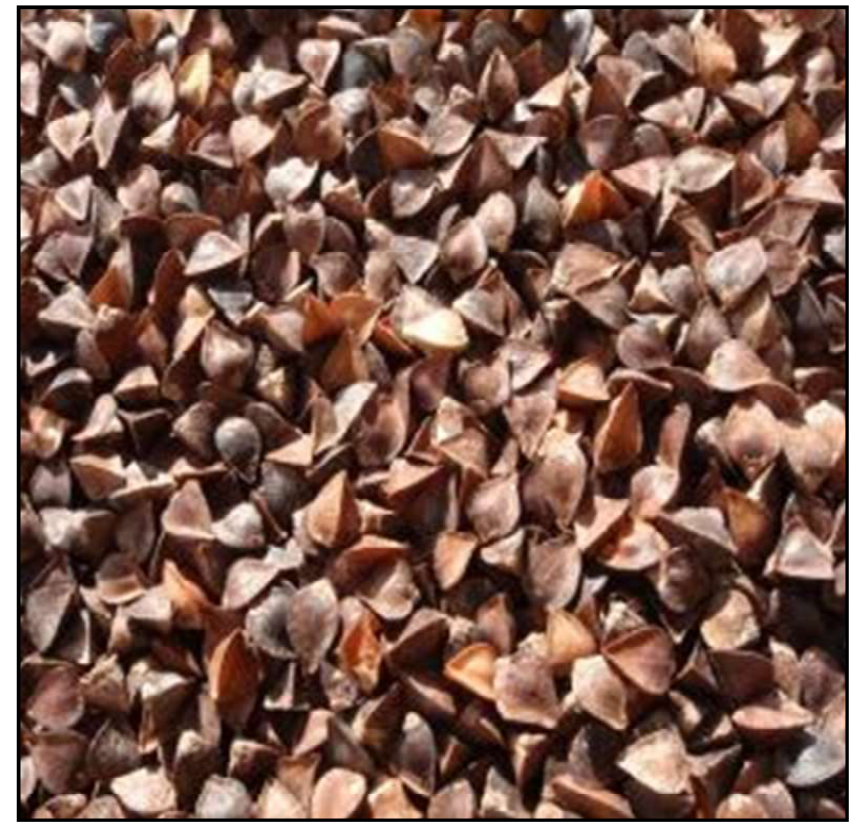

Figure 1: Buckwheat seeds.

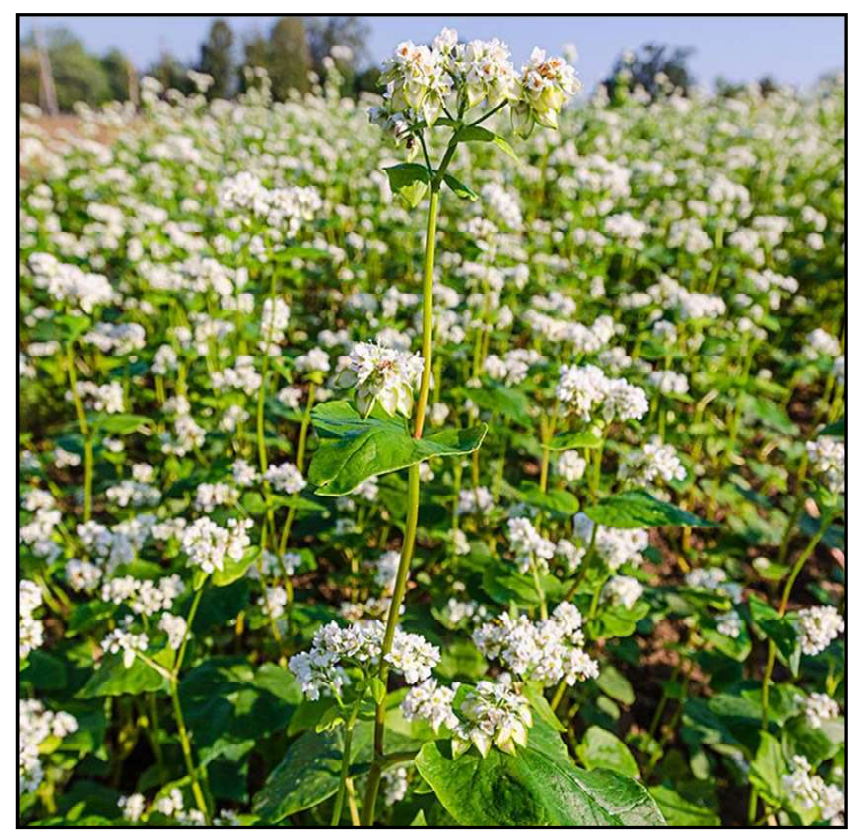

Figure 2: Buckwheat inflorescence.

\subsection{Geographical distribution}

Among many species of buckwheat, only 9 species grown around the world have nutritional value and only 2 out of these 9 are used as food, viz., common buckwheat (F. esculentum) and tartary buckwheat (F. tataricum). Buckwheat is known by various names around the world, Yi people of the Yunnan province called common buckwheat er chi (Li and Zhang, 2001), mite phapar in Nepal, soba in Japan, jawas in Pakistan, tianqiaomai in Mandarin, jare in Bhutan, grecichakul'furnaja in Russia and tatarkagryka or poganka in Poland (Campbell, 1997).
Many nutraceutical compounds are found in buckwheat seeds, flowers and in other tissues. It contains many essential compounds for diet, such as proteins with essential amino acids (Deficient in staple foods) and high biological value, phenolic compounds and dietary fibre. Buckwheat seed also contains several forms of phenols like: flavonoids and flavones, plant sterols, fagopyrins, thiamine binding proteins, allergenic proteins and their derivatives, which have the healing benefits for human beings.

The area of "Nutri cereals [Finger millets and minor millets: Foxtail millets, proso millet, kodo millet, barrnyard millet, little millet and pseudo millets (Buckwheat + Amaranthus)]" is 25.01 million hectares and production was about 43.77 million tons in 2016-2017, as compared to 43.80 million hectares and 30.41 million tons in 197576 (Directorate of Economics and Statistics, Department of Agriculture, Cooperation and farmers welfare, Government of India, 2018).

Major cultivation areas are located in Asia and particularly in Southeast Asia, where crops are grown on marginal and fairly unproductive land. In these areas, it is often cultivated as a subsistence crop with barley, often at higher altitudes (Campbell, 1997). Buckwheat is cultivated from Jammu and Kashmir in the north to Arunachal Pradesh in the east and Tamil Nadu in the South. Areas with major cultivation include Bharmaur, Pangi, outer Saraj, Chopal in Himachal Pradesh; Kargil and Drass sectors, Gurez valley of Jammu and Kashmir; Cooch Behar, Darjeeling in West Bengal; Lachan, Lachoong in Sikkim; Tawang, Bomdilla and Dirang in Arunachal Pradesh, Nilgiris and Palani hills in the southern part of India. Buckwheat is quickly gaining popularity in majority of northern states, viz., Uttarakhand, Himachal Pradesh owing largely to the suitable climate (Rana et al., 2012).

The hilly regions of Uttarakhand with many diverse eco-geographical cultivation hubs are more suitable for hardy crops along the lines of small millets, amaranthus, buckwheat and chenopods. Pindari valley, Darma valley, Jolwan, Jaunpur, Kapkote in Uttarakhand are some of the major areas of cultivation (Rana et al., 2012). Many species of buckwheat are grown around the world; however, only nine have agricultural and nutritional value (Krkoskova and Mrazova, 2005). Common buckwheat ( $F$. esculentum) is also used as a vegetable because of its sweet taste and large, easily de-hulled seeds and in many areas of the Indian subcontinent, it is raised as a leafy vegetable crop, the leaves and young shoots is boiled and eaten just like spinach (Campbell, 1997; Paulickova, 2008). In most countries, buckwheat in modern time not eaten mainly to satiate the people's hunger and to get food energy. Traditionally, Buckwheat is eaten for its taste, and mostly used in food products for human health due to its valuable active ingredients. These demands and reasons for consuming buckwheat may be met solely by buckwheat products of highest possible quality, with typical and clearly pronounced taste and with the content of all nutrients, important for human health, and free from chemicals (Christa, Soral-Śmietana, 2008).

Tartary buckwheat is more prevalent in lands above $2500 \mathrm{~m}$, common buckwheat however is grown at lower elevations extending to $1000 \mathrm{~m}$. Common buckwheat cultivation in Tibet Himalayas was limited to approximately $500-2500 \mathrm{~m}$ in altitude and above $2500 \mathrm{~m}$ tartary 
buckwheat is preferably grown. Buckwheat is cultivated easily, have a short growing period and a long storage time without changes in its chemical composition due to phenolic and antioxidant activity (Ohnishi, 1989).

\section{Biochemical composition}

Seed is mainly consumed as food, as it is a rich source of variety of biochemical ingredients like starch, proteins, antioxidative substances, trace elements and dietary fibre in appreciable amount
(Bonafaccia et al., 2003). It is reported that whole buckwheat contains 2-5 times more phenolic compounds than oats or barley and buckwheat bran and hulls have 2-7 times higher antioxidant activity than barley, triticale and oats (Holasova et al., 2002). Leaves and stem also have hyperoside (quercetin), gallic-3-Oglucoside chlorogenic acid, neochlorogenic acid present in them (Hagels et al., 1995). Comparison of various nutritional ingredients among buckwheat and other commonly used cereals is shown in Table 1.

Table 1: Comparison of biochemical parameters of buckwheat with other commonly used cereals (Przybylski and Gruczynska, 2009; Zhao et al., 2001; Youssef et al., 2016, Dogra and Awasthi, 2017)

\begin{tabular}{|c|c|c|c|c|c|c|c|}
\hline \multirow[t]{2}{*}{ Nutrient } & \multicolumn{2}{|c|}{ Buckwheat } & \multirow[t]{2}{*}{ Wheat } & \multirow[t]{2}{*}{ Rye } & \multirow[t]{2}{*}{ Barley } & \multirow[t]{2}{*}{ Corn } & \multirow[t]{2}{*}{ Oat } \\
\hline & Common & Tartary & & & & & \\
\hline $\begin{array}{l}\text { Moisture } \\
\text { Energy } \\
\text { Protein } \\
\text { Lipids } \\
\text { Ash } \\
\text { Carbohydrates } \\
\text { Fibre } \\
\text { Protein in flour } \\
\text { Calcium } \\
\text { Iron } \\
\text { Magnesium } \\
\text { Phosphorus } \\
\text { Potassium } \\
\text { Sodium } \\
\text { Zinc } \\
\text { Copper } \\
\text { Manganese } \\
\text { Selenium }\end{array}$ & $\begin{array}{r}8.9 \\
343.0 \\
13.3 \\
2.8 \\
2.1 \\
71.5 \\
12.6 \\
19.0 \\
18.0 \\
2.2 \\
231.0 \\
347.0 \\
460.0 \\
1.0 \\
2.4 \\
1.1 \\
1.3 \\
8.3\end{array}$ & $\begin{array}{r}10.2 \\
328.0 \\
10.3 \\
2.5 \\
1.8 \\
74.3 \\
6.3 \\
18.9 \\
15.0 \\
- \\
240.0 \\
- \\
- \\
- \\
0.02 \\
0.05 \\
- \\
0.05\end{array}$ & $\begin{array}{r}10.9 \\
339.0 \\
13.7 \\
2.5 \\
1.8 \\
71.1 \\
11.2 \\
10.3 \\
25.0 \\
3.6 \\
124.0 \\
332.0 \\
340.0 \\
2.0 \\
2.8 \\
0.4 \\
4.1 \\
70.7\end{array}$ & $\begin{array}{r}10.9 \\
335.0 \\
14.8 \\
2.5 \\
2.0 \\
69.8 \\
14.6 \\
14.3 \\
33.0 \\
2.7 \\
121.0 \\
374.0 \\
264.0 \\
6.0 \\
3.7 \\
0.5 \\
2.7 \\
35.3\end{array}$ & $\begin{array}{r}9.4 \\
354.0 \\
12.5 \\
2.3 \\
2.3 \\
73.5 \\
17.3 \\
10.5 \\
33.0 \\
3.6 \\
133.0 \\
264.0 \\
452.0 \\
12.0 \\
2.8 \\
0.5 \\
1.9 \\
37.7\end{array}$ & $\begin{array}{r}10.4 \\
365.0 \\
9.4 \\
4.7 \\
1.2 \\
74.3 \\
7.3 \\
6.9 \\
7.0 \\
2.7 \\
127.0 \\
210.0 \\
287.0 \\
35.0 \\
2.2 \\
0.3 \\
0.5 \\
15.5\end{array}$ & $\begin{array}{r}8.20 \\
389.00 \\
16.90 \\
6.90 \\
1.70 \\
66.30 \\
10.70 \\
14.70 \\
54.70 \\
13.76 \\
120.67 \\
472.57 \\
350.00 \\
5.35 \\
3.44 \\
1.33 \\
4.42 \\
-\end{array}$ \\
\hline
\end{tabular}

Minerals composition is shown in $\mathrm{mg} / 100 \mathrm{~g}$ and others are in $\%$.

A total of $55 \%$ starch, $12 \%$ protein, $4 \%$ lipid, $2 \%$ soluble carbohydrates, $7 \%$ total dietary fiber, $2 \%$ ash is present in whole buckwheat groats. The variation in content varies with different buckwheat species. The oat flour has more protein than buckwheat flour, but is still significantly more than rice, wheat, millet, sorghum and maize. $\mathrm{K}, \mathrm{Mg}, \mathrm{P}, \mathrm{Fe}, \mathrm{Ca}, \mathrm{Cu}, \mathrm{Zn}, \mathrm{Se}, \mathrm{Ba}, \mathrm{B}$, and $\mathrm{Co}$ are some of the common and rare minerals, found in buckwheat, but are concentrated in outer layers of seed and hulls (Steadman et al., 2001a). Milling is done to process buckwheat groats into light flour (most common, use to make pancakes, breads and soba noodles) and various other grades of flour (Tomotake, 2002).

Buckwheat bran is a rich source of total dietary fiber and soluble dietary fiber and hulled bran is richer that dehulled bran (Steadman et al., 2001a). Phenolic acids and flavanoids are rich in methanol extract while tocopherols are reported in the hexane extract of buckwheat seed (Christa and Soral-Smietana, 2008). Several gluten free grains of pseudocereals: amaranth, quinoa and buckwheat, are characterized by excellent nutrient profile for human consumption. Contrary to most common grains, the proteins in amaranth, quinoa and buckwheat are composed mainly of globulins and albumins, and contain very little or no prolamin proteins, which are the main storage proteins in cereals, and also the toxic proteins in celiac disease (Tahir and Farooq, 1985; Drzewiecki et al., 2003).

The amino acid composition of globulins and albumins differs significantly from that of prolamins, which has implications in relation to their nutritional quality. Globulins and albumins contain less glutamic acid and proline than prolamins, and more essential amino acids such as lysine (Drzewiecki et al., 2003).

In view of the increasing importance of seed proteins in human nutrition, considerable research efforts have been made for the improvement of protein quality of food grains as a whole. Undoubtedly, cereal and legume proteins form the major food proteins consumed by humans and contribute significantly towards food technological innovations. Efforts seem to have been made in the past to investigate the profile of these underutilized plant proteins. Incidentally, the study on buckwheat proteins is not so much accomplished as compared to those on rice, wheat and soybean proteins, although buckwheat grains are used in roasted form and flour is used for making pudding, pilaf, roti, laddu and fried items with boiled potato (Pomeranz et al., 1975). Various essential components found in common and tartary buckwheat is shown in Table 2. 
Table 2: Biochemical composition $(\mathrm{mg} / \mathrm{g})$ of common and tartary buckwheat

\begin{tabular}{|l|l|l|}
\hline Component & $\begin{array}{l}\text { Common buckwheat } \\
\text { (Wijngaard and Arendt, } \\
\text { 2006; Steadman } \text { et al., } \\
\text { 2001b; Rauf } \text { et al., 2019) }\end{array}$ & $\begin{array}{l}\text { Tartary Buckwheat } \\
\text { (Zhao et al., 2001; } \\
\text { Tuan } \text { et al., 2013; } \\
\text { Zhou al. 2015; } \\
\text { Vombergar } \text { et al., 2020) }\end{array}$ \\
\hline Flavonoid content & 0.88 & 263.90 \\
Rutin content (groat) & $0.2-0.3$ & 81.00 \\
Rutin content (hull) & $0.8-4.4$ & $0.60-3.70$ \\
Rutin content (sprout) & 5.50 & 27.30 \\
Quercetin (groat) & 0.001 & 0.008 \\
Quercetin (hull) & 0.029 & 0.038 \\
Quercetin (sprout) & 0.78 & 12.23 \\
A (Beta- carotene) & 2.10 & 0.02 \\
B $_{1}$ (thiamine) & 4.60 & 0.19 \\
B $_{2}$ (riboflavin) & 1.40 & 0.55 \\
B $_{3}$ (niacin) & 18.00 & 2.61 \\
C (ascorbic acid) & 50.00 & 7.10 \\
E (tocopherols) & 54.60 & 13.00 \\
\hline
\end{tabular}

The knowledge of status of various buckwheat proteins including glutelins and prolamin might be useful in understanding the physicochemical attributes as witnessed in wheat glutens in the preparation of food products. The protein content varied among different buckwheat species and has similar qualitative characteristics to the protein content in cereal grains. Compared to cereals, the amino acid composition of buckwheat is characterized by higher contents of aspartic acid, lysine and arginine, and less glutamic acid and proline (Table 3). Due to the high lysine content, buckwheat has a higher nutritional value than other cereal grains because lysine is the first limiting amino acid from this protein source (Bonafaccia et al., 2003). Lowest Lys/Arg ratio (0.56) is found in samples collected from Palampur and Lahul valley (Figure 3). Buckwheat with low lysine to arginine ratio has been postulated to be responsible for hyperlipidemic effect (Verma, 2018; Gopalan et al., 1989). Grains contain moisture, protein, fat, mineral matter, fiber, carbohydrates, calcium, and phosphorus along with reported traces of nickel, copper, cobalt and zinc, phytin, iodine and riboflavin. F. esculetum protein concentrate and hydrolysate have potential usefulness as food ingredients (Morishita et al., 2002).

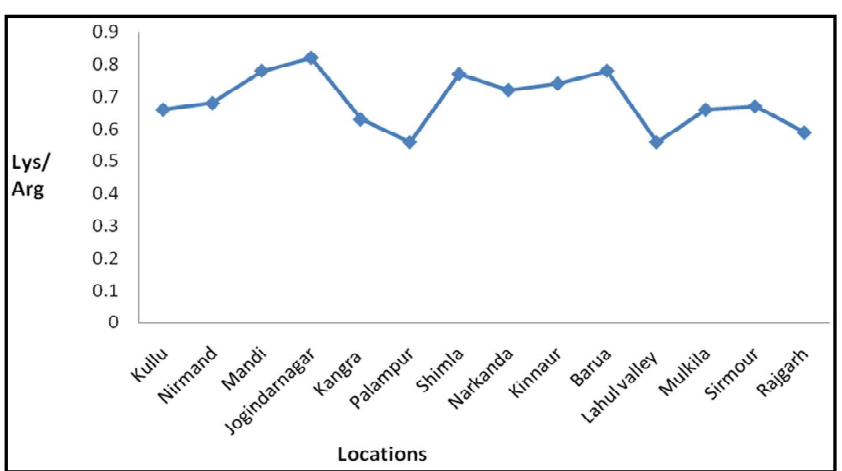

Figure 3: Lys/Arg ratio among collected samples from various locations (Verma, 2018).
Table 3: Variability in amino Acid profiling of common buckwheat grains $(\% \mathrm{w} / \mathrm{w})$

\begin{tabular}{|l|l|l|l|}
\hline Amino acids & $\begin{array}{l}\text { Soral-Smietana } \\
(1984)\end{array}$ & $\begin{array}{l}\text { Wei } \text { et al. } \\
(2003)\end{array}$ & $\begin{array}{l}\text { Tomotake } \text { et al. } \\
(2006)\end{array}$ \\
\hline Lysine & 6.17 & 4.9 & 5.68 \\
Histidine & 2.44 & 1.4 & 2.52 \\
Arginine & 8.85 & 5.4 & 11.16 \\
Glutamic acid & 15.37 & 9.7 & 19.38 \\
Aspartic acid & 9.10 & 5.2 & 9.54 \\
Threonine & 4.04 & 1.9 & 3.5 \\
Serine & 4.89 & 2.4 & 4.61 \\
Proline & 4.57 & 2.6 & 7.93 \\
Glycine & 6.23 & 4.2 & 5.66 \\
Alanine & 4.82 & 3.0 & 3.89 \\
Valine & 4.97 & 3.4 & 4.26 \\
Isoleucine & 3.41 & 2.6 & 3.12 \\
Leucine & 6.12 & 2.8 & 5.94 \\
Methionine & 0.99 & 1.6 & 2.3 \\
Tyrosine & 1.94 & 1.5 & 3.03 \\
Phenylalanine & 4.42 & 2.0 & 4.3 \\
Tryptophan & 2.14 & 1.5 & 2.0 \\
\hline
\end{tabular}

Buckwheat is used in many traditional ways in form of medicine and as a food. The cooked buckwheat leaves in iron vessels cure constipation and anemia (Pant et al., 2009). Dyes are prepared and used on textile fabric from the hull of the seed and its perisperm is used as fuel in producer gas plants. For renovation of low productivity, land buckwheat is useful as a green manure crop, as it grows well on such land in short time also providing improved soil texture and increased productivity of other crops also is used as a smother crop (Campbell, 1997; Joshi, 1999).

Table 4: Fatty acid profile $(\mathrm{mg} / \mathrm{g})$ of tartary and common buckwheat

\begin{tabular}{|l|l|l|}
\hline Fatty acids & $\begin{array}{l}\text { Tartary buckwheat } \\
\text { (Zhang et al., 2016) }\end{array}$ & $\begin{array}{l}\text { Common buckwheat } \\
\text { (Ahmed et al., 2014) }\end{array}$ \\
\hline C16:0 & 124 & 186 \\
C18:0 & 12 & 19 \\
C18:1 & 395 & 359 \\
C18:2 & 389 & 344 \\
C18:3 & 14 & 22 \\
C20:0 & 15 & 14 \\
C20:1 & 26 & 30 \\
C22:0 & 15 & 14 \\
C22:1 & 5 & 2 \\
C24:0 & 6 & 9 \\
\hline
\end{tabular}

The grain and hulls consist of flavonoids and flavones, phenolic acids, condensed tannins, pytosterols and fagopyrin. Many bioactive ingredients like rutin, orientin, vitexin, quercetin, isovitexin and isoorientin are present in hulls of $F$. esculentum (Figure 4; Hung and Morita, 2008).

The usefulness of buckwheat can be conferred to its prosperity in medicinally active components, along with its curative potential. It also has many prophylactic effects. Besides high-quality protein, buckwheat also has several other medicinally active components like, trace elements, dietary fibers, phenols, phytosterols, D-chiroinositol derivative, imino-sugars, fatty acid, and minerals, etc. (Krkošková and Mrázová, 2005). Tartary and common buckwheat 
having fatty acid composition as of oilseed crops, along with good amount of essential fatty acids (Table 4).

Resistant starch (RS) is a small fraction of starch that is resistant to hydrolysis by amylase. The starch that is not hydrolysed after 120 min of incubation at $37{ }^{\circ} \mathrm{C}$ is called resistant starch. However, starch reaching the large intestine may be more or less fermented by the gut microflora (Englyst et al., 1982). Seeds of buckwheat having high amount of starch (Skrabanja and Kreft, 1998). Buckwheat flour contains 700-910 mg/g of starch depending on the flour types, and the starch consists of $250 \mathrm{mg} / \mathrm{g}$ amylase and $750 \mathrm{mg} / \mathrm{g}$ amylopectin (Qin et al., 2010; Takahama and Hirota, 2010).

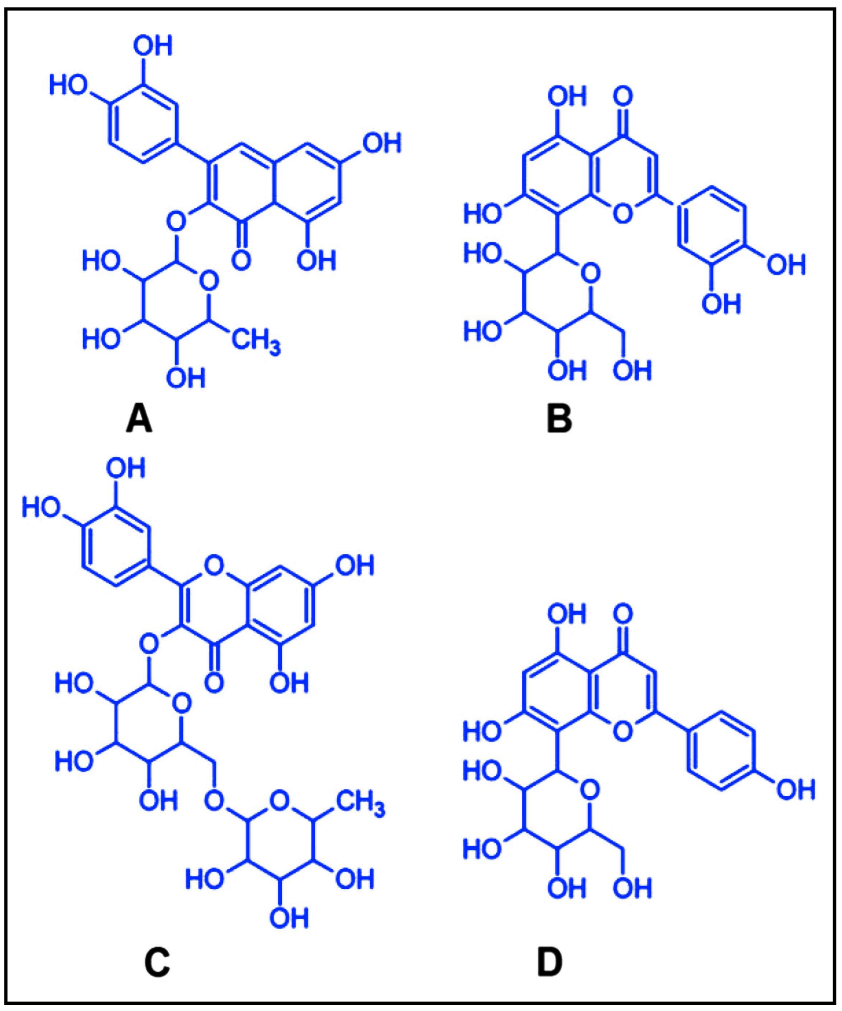

Figure 4: Important phenolic compounds in buckwheat: A, isorientin; B, orientin; C, rutin; D, vitexin (Verardo et al., 2011).

Consumption of boiled buckwheat groats or bread baked using $0 \cdot 50 \%$ buckwheat flour induced significantly lowered postprandial blood glucose and insulin responses compared with white wheat bread. Buckwheat products provide important source of retrograded starch and resistant starch, RS (Christa and Soral-Smietana, 2008). Inclusion of around $30 \mathrm{~g}$ buckwheat in the daily diet has been sufficient to produce clinically relevant reductions in serum total and LDL-cholesterol, triglycerides and increases in HDL-cholesterol, thus reducing the risk of cardiovascular diseases (CVD). These results support the view that buckwheat proteins and RS could have beneficial effects on various diseases, including hyperlipidemia. Buckwheat in the diet of non-independent insulin diabetes mellitus (NIDDM) led to a significant reduction in their fasting and postprandial blood glucose levels since it is rich in D-chiro-inositol, which contributes to the improvement of insulin resistance by enhancing the action of insulin (He et al., 1995).
Antioxidant activity is the fundamental prophylactic property which is important for humans. Buckwheat seed bran and seed hulls having 2-7 folds higher antioxidant activity as compared to barley, triticale and oats (Holasova et al., 2002; Zdunczyk et al., 2006). The antioxidant activities of buckwheat are comparable to butylated hydroxyanisole (BHA), butylated hydroxytoluene (BHT) and tertiary butylhydroquinone (TBHQ), as determined by 1,1diphenyl-2-picrylhydrazyl (DPPH) assay and the Rancimat method (Sun and Ho, 2005).

\subsection{Buckwheat flavonoids: A high value secondary metabolite}

Flavonoids are polyphenolic includes more than 4000 compounds. They are naturally occurring ubiquitous compounds in plants. They possess a variety of biological activities at non-toxic concentrations in organisms. They have a common structure of phenylbenzopyrone in form of C6-C3-C6 and categorized as per saturation level and opening of the central pyran ring. They are mainly divided into flavones, flavanols, isoflavones, flavonols, flavanones and flavanonols (Ren et al., 2003). Four flavonol glycosides including rutin, quercetin, kaemferol-3-rutinoside and a trace amount of a flavonol triglycoside were found in the methanol extract of buckwheat (Tian and Patel, 2002). Buckwheat contains more rutin compared with other grain crops. This is a quercetin-3-rutinoside with antioxidant, anti-inflammatory and anticarcinogenic properties, and it can also reduce the fragility of blood vessels related to haemorrhagic disease and hypertension in humans (Baumgertel et al., 2003).

Buckwheat tissues serve as useful resources for high-quality flavonoids, though flavonoid content varies with development and is significantly influenced by the contents of phenylalanine and tyrosine and the activity of kinetin in the issues with other existing forms of $\mathrm{N}_{2}$ in the soil (Li and Zhang, 2001). The main constituents for antioxidant activity in buckwheat seed are rutin and quercetin. Quercetin shows higher antioxidant activity as compared to rutin (Ya-ping et al., 2008). Seeds are a good source of dietary rutin (Koda et al., 2008), as it is not found in other cereal and pseudocereal except $F$. esculentum (Buckwheat). About $80-90 \%$ rutin is present in leaves and flower (Pullaiah, 2006) and during blossom, rutin is at its peak and relatively only a small amount is present in stems and completely absent in fruits (Tang et al., 2009). Younger leaves contain more rutin than older leaves. Buckwheat rutin has antioxidant, anti-inflammatory and anticarcinogenic properties, and helps in haemorrhagic disease and hypertension as it can also reduce the fragility of blood vessels. Rutin (quercetin-3-beta-D-rutinoside) is an important therapeutic substance that influences the increase of blood vessel elasticity (Mukasa et al., 2009), to reduce the blood pressure, for treatment of atherosclerosis and to stimulate the uptake of vitamin $\mathrm{C}$ (Yildizog־lu-Ari et al., 1991). Buckwheat rutin may be used as antioxidant for human consumption (Ohsawa and Tsutsumi, 1995; Watanabe, 1998; Park et al., 2003; Jiang et al., 2007). Different cultivars of buckwheat have different contents of rutin with potential variation also in different plant parts (Ohsawa and Tsutsumi, 1995).

\section{Applications in food industry}

Due to the potential health benefits, buckwheat has been receiving increasing attention as a potential functional food and various buckwheat-based products for example bread, cakes, noodles, honey, 
tea, tarhana, alcoholic beverages (beer, shochu), vinegar, sprouts have been developed and are available in the food market. Buckwheat honey is known for its health benefits due to the presence of p-hydroxybenzoic, p-coumaric, benzoic, abscisic acids, flavonoids and elevated antioxidant potential (Gheldof et al., 2003).

The presence of fiber, rutin and no gluten makes it an appropriate crop for today's world which is drifting away from healthy habits. Absence of gliadin and gluten in buckwheat is another plus point in the significant increase, in the use of the pseudocereal for developing gluten-free products. These active compounds will be immensely helpful in improving various traditional and local buckwheat foods. Proper utilization of buckwheat crop constituents will also promote food industries for the development of new functional foods. The nutraceutical potential of buckwheat, its wide use in food products and possible solutions to overcome its limitation to become a sustainable and staple crop demands the need to further exploit the use of bioactive compounds ( $\mathrm{Li}$ and Zhang, 2001). Buckwheat flour products as a supplement with milk proteins and cereals may be used as fast consuming food/convenient food (Śmietana et al., 1988). Buckwheat flour fortified with other cereals may be used to produce multicomponent mixtures for higher nutritive value (Fornal, 1987).

\section{Therapeutic potential}

For celiac patients, buckwheat flour may be a valuable ingredient in diets. Celiac disease is an gluten sensitive enteropathy, small intestine linked gluten intolerance disorder, it is determined genetically. However, an increase is also observed in the incidence of the so called potential celiac disease, particularly in adult patients. Buckwheat proteins may show a strong supplemental effect with other vegetable proteins due to the well balanced amino acid composition (Li and Zhang, 2001).

Buckwheat proteins can exert a strong cholesterol-lowering effect and have a high biological value (Huff and Carroll, 1980; Sugiyama et al., 1985). The protein components of buckwheat in diets significantly decreases the serum cholesterol levels in liver and gallbladder of hamsters and, thus inhibits the formation of gallstones by altering cholesterol metabolism (Tomotake et al., 2002), whereas protein extracts are more efficient in lowering the blood cholesterol level, particularly that of low density lipoprotein and very low density lipoprotein (Kayashita et al., 1995; Tomotake et al., 2006). The hypocholesterolemic effect in humans is linked with a lower digestibility of buckwheat proteins and the presence of fibre-like substances, which is indicated by an increase in the contents of neutral and acid sterols in rat faeces observed upon the administration of a diet rich in buckwheat protein products (Kayashita et al., 1997; Tomotake et al., 2001). They are also associated with the suppression of colon carcinogenesis by reducing cell proliferation and with the suppression of mammary carcinogenesis by lowering serum estradiol. They can inhibit gallstone formation better as compared to soy protein (Tomotake et al., 2000).

Numerous experiments have proved that buckwheat proteins extract may be used as a potential functional food additive to treat hypertension, obesity, alcoholism, as well as constipation (Kato et al., 2001; Tomotake et al., 2002). In buckwheat, grains fibre contains about $7 \%$ of the soluble fraction, whereas resistant starch constitutes about $28 \%$ of total starch in the whole grain (Stempińska and Soral-Śmietana, 2006). Buckwheat products may be considered as potential prebiotic components in human gastrointestinal tract (Préstamo et al., 2003).

Honey obtained from buckwheat flowers increases the antioxidative potential of human blood serum and in vitro studies indicated that it protects lipoproteins of blood serum against oxidative processes more effectively than saccharic analogues (Gheldof et al., 2003). The most interesting fact for the food industry is the improvement of functional properties of food as well as the health-promoting benefits resulting from food consumption.

Buckwheat consumption reduces risk of diabetes because of its high content of magnesium. It also cures the condition because of chiro-inositol present in it (Kawa et al., 2003). Buckwheat alters cholesterol metabolism, thus helpful in avoiding gallstones (Prakash and Yadav, 2016). The high fiber content and plant lignans make buckwheat helpful in reducing risk related to colon cancer, breast cancer, and cardiovascular problems. Postmenopausal consumption of its grains is beneficial for a person with high cholesterol, high blood pressure, and cardiovascular problems. Buckwheat seed extracts possess radical inhibitors or scavengers with possibility to act as primary antioxidants by reduction of DPPH radicals. Perhaps, they react with free radicals, especially with the peroxy radicals. Peroxy radicals are the major cause of the auto-oxidation in lipids (Shahidi and Wanasundara, 1992).

\section{Limitations in buckwheat cultivation}

Major disadvantages of buckwheat cultivation is of low grain yield, harvesting problem as seed is more asynchronous as compared to other cereals, frost intolerance, set seeds quickly and can become a weed problem (Ahmed et al., 2014; Luitel et al., 2017). In many areas common buckwheat is replaced by finger millet or other crop due to lower yielding ability of buckwheat. Buckwheat seeds ripen more asynchronously, it results in harvesting problems technically. Allergy to buckwheat was first reported in 1909, and it is mostly an immediate IgE-mediated reaction that can cause a severe allergic reaction similar to that caused by peanut allergy (Smith, 1909). Several buckwheat allergens have been identified (Tohgi et al., 2011), out of which, the $16 \mathrm{kDa}$ protein (Fage 2), which is resistant to digestion, has been identified as a major buckwheat allergen in Japanese and Korean patients (Park et al., 2000). Allergic reactions after the consumption of buckwheat food, in their worst form, cause hemorrhagic disease, connected with a rapid decrease of blood pressure known as the anaphylactic shock (Heffler et al., 2007).

\section{Conclusion}

There is tremendous potential in growing buckwheat as a food crop and also as a food of nutritional value. The presence of fiber, rutin and no gluten makes it an appropriate crop for today's world which is drifting away from healthy habits. Unique protein material like polyphenol rich proteins, are used for production of hydrolysates having excellent antioxidant activity like DPPH scavenging ability, reducing power and also the polyphenol content enhanced the ability to inhibit linoleic acid peroxidation. Many other benefits are quite 
evident from various reports from all around the world by consumption of buckwheat, which has shown a interest in buckwheat cultivation and its uses since the last two decades. On the other hands, common buckwheat has some problem in form of low grain yield, quick seed set and frost tolerance. The inherent properties of antioxidant and prophylactic characters make buckwheat an attractive crop for further research.

\section{Conflict of interest}

The authors declare that there are no conflicts of interest relevant to this article.

\section{References}

Ahmed, A.; Khalid, N.; Ahmad, A.; Abbasi, N. A.; Latif, M. S. Z. and Randhawa, M. A. (2014). Phytochemicals and biofunctional properties of buckwheat: A review. The Journal of Agricultural Science, 152:349-369.

Baumgertel, A.; Grimm, R.; Eisenbeiss, W. and Kreis, W. (2003). Purification and characterization of a flavonol 3-o-betaheterodisaccharidase from the dried herb of Fagopyrum esculentum Moench. Phytochemistry, 64:411-418.

Bonafaccia, G.; Marocchini, M. and Kreft, I. (2003). Composition and technological properties of the flour and bran from common and tartary buckwheat. Food Chemistry, 80:9-15.

Campbell, C. G. (1997). Promoting the conservation and use of underutilized and neglected crops. 18. Institute of Plant Genetics and Crop Plant Research. Gatersleben/International Plant Genetic Resources Institute, Rome, Italy.

Christa, K. and Soral-Smietana, M. (2008). Buckwheat grains and buckwhea products-nutritional and prophylactic value of their components: A review. Czech Journal of Food Science, 26:153-162.

Dogra, D. and Awasthi, C. P. (2017). Biochemical composition of promising leaves genotypes of buckwheat grown in Himachal Pradesh. Journal of Applied and Natural Science, 9:875-878.

Dol, R. L.; Siwakoti, M.; Jha, P. K.; Jha, A. J. and Krakauer, K. (2017). An overview: Distribution, production, and diversity of local landraces of buckwheat in Nepal. Advances in Agriculture, 1:1-6.

Drzewiecki, J.; Delgado-Licon, E.; Haruenkit, R.; Pawelzik, E.; Martin-Belloso, O.; Park, Y.; Jung, S. T.; Trakhtenberg, S. and Gorinstein, S. (2003). Identification and differences of total proteins and their soluble fractions in some pseudocereals based on electrophoretic patterns. Journal of Agricultural and Food Chemistry, 51:7798-7804.

Englyst, H. N.; Kingman, S. M. and Cummings, J. H. (1992). Classification and measurement of nutritionally important starch fractions. European Journal of Clinical Nutrition, 46:33-50.

Englyst, H. N.; Wiggins, H. S. and Cummings, J. H. (1982). Determination of the non-starch polysaccharides in plant foods by gas-liquid chromatography of constituent sugars as alditol acetates. Analyst, 107:307-318.

Fornal, L.; Śmietana, Z.; Soral-Śmietana, M. and Szpendowski, J. (1987) Chemical characteristics and physico-chemical properties of the extruded mixtures of cereal starches. Starch/Stärke, 39:75-78.

Gheldof, N.; Wang, X. and Engeseth, N.J. (2003). Buckwheat honey increases serum antioxidant capacity in humans. Journal of Agriculture and Food Chemistry, 51:1500-1505.

Gopalan, C.; Rama Sastri, B.V. and Balasubramanian, S.C. (1989). Nutritive value of Indian foods. NIN (ICMR). Hyderabad, pp:47-85.
Hagels, H.; Wagenbreth, D. and Schilcher, H. (1995). Phenolic compounds of buckwheat herb and influence of plant agricultural factors (Fagopyrum esculentum Moench and Fagopyrum tataricum Gartner). Current Advance in a Buckwheat Research, 1:801-809.

He, J.; Klag, M. J.; Whelton, P. K.; Mo, J. P.; Chen, J. Y.; Qian, M. C.; Mo, P. S. and He, G. Q. (1995). Oats and buckwheat intakes and cardiovascular disease risk factors in an ethnic minority of china. American Journal of Clinical Nutrition, 61:366-372.

Heffler, E.; Guida, G.; Badiu, I.; Nebiolo, F.; Rolla, G. (2007). Anaphylaxis after eating italian pizza containing buckwheat as the hidden food allergen. Journal of Investigational Allergology and Clinical Immunology, 17(4):261-263.

Holasova, M.; Fiedlerova, V.; Smrcinova, H.; Orsak, M.; Lachman, J. and Vavreinova, S. (2002). Buckwheat-the source of antioxidant activity in functional foods. Food Research International, 35:207-211.

Huff, M.W. and Carroll, K.K. (1980). Effects of dietary protein on turnover, oxidation, and absorption of cholesterol, and on steroid excretion in rabbits. Journal of Lipid Research, 21:546-548.

Hung, V. and Morita, N. (2008). Distribution of phenolic compounds in the graded flours milled from whole buckwheat grains and their antioxidant capacities. Food Chemistry, 109:325-331.

Jiang, P.; Burczynski, F.; Campbell, C.; Pierce, G.; Austria, J. A. and Briggs, C. J. (2007). Rutin and flavonoid contents in three nutritional profile of buckwheat 365 buckwheat species Fagopyrum esculentum, F. tataricum, and $F$. homotropicum and their protective effects against lipid peroxidation. Food Research International, 40:356-364.

Joshi, B. D. (1999). Status of Buckwheat in India. Fagopyrum, 16:7-11.

Joshi, B. D. and Paroda, R. S. (1991). Buckwheat in India. Science monograph 2, National Bureau of Plant Genetic Resources, New Delhi, pp:117.

Kato, N.; Kayashita, J. and Tomotake, H. (2001). Nutritional and physiological functions of buckwheat protein. Recent Research Development Nutrition, 4:113-119.

Kawa, J.M.; Taylor, C.G. and Przybylski, R. (2003). Buckwheat concentrate reduces serum glucose in streptozotocin-diabetic rats. Journal of Agricultural and Food Chemistry, 51:7287-7291.

Kayashita, J.; Shimaoka, I. and Nakajoh, M. (1995). Hypocholesterolemic effect of buckwheat protein extract in rats fed cholesterol enriched diet. Nutrition Research, 15:691-698.

Kayashita, J.; Shimaoka, I.; Nakajoh, M.; Yamazaki, M. and Kato, N. (1997). Consumption of buckwheat protein lowers plasma cholesterol and raise faecal neutral sterols in cholesterol-fed rats because of its low digestibility. Journal of Nutrition, 127:1395-1400.

Koda, T.; Kuroda, Y. and Imai, H. (2008). Protective effect of rutin against spatial memory impairment induced by trimethyltin in rats. Nutrition Research, 28:6299-634.

Krkošková, B. and Mrazova, Z. (2005). Prophylactic components of buckwheat. Food Research International, 38:561-568.

Li, S. and Zhang, Q. H. (2001). Advances in the development of functional foods from buckwheat. Critical Reviews in Food Science and Nutrition, 41:451-464.

Loch, J. and Lazanyi, J. (2010). Soil nutrient content in buckwheat production. European Journal of Plant Science and Biotechnology, 4:93-97.

Morishita, T.; Hara, T.; Suda, I. and Tetsuka, T. (2002). Radical-scavenging activity in common buckwheat (Fagopyrum esculentum Moench) harvested in the Kyushu region of Japan. Fagopyrum, 19:89-93. 
Muhammad, R.; Yoon, H.; Lee, S.; Hyun, D. Y.; Lee, M.; Oh, S. and Choi, Y. (2019). Evaluation of sprout growth traits and flavonoid content in common and tartary buckwheat germplasms. Plant Breeding and Biotechnology, 7:375-385

Mukasa, Y.; Suzuki, T. and Honda, Y. (2009). Suitability of rice-tartary buckwheat for crossbreeding and for utilization of rutin. JarqJapan Agricultural Research Quarterly, 43:199-206.

Ohnishi, O. (1989). Cultivated buckwheat species and their relatives in the Himalaya and southern China. In Proc. 4th Intl. Symp, Buckwheat, pp:562-571.

Ohsawa, R. and Tsutsumi, T. (1995). Inter-varietal variations of rutin content in common buckwheat flour (Fagopyrum Esculentum Moench). Euphytica, 86:183-189.

Pant, S.; Samant, S.S. and Arya, S.C. (2009). Diversity and indigenous household remedies of the inhabitants surrounding Mornaula reserve forest in west Himalaya. Indian Journal of Traditional Knowledge, 8:606-610.

Park, C.H.; Kim, Y.B.; Choi, Y.S.; Heo, K.; Kim, S.L.; Lee, K.C.; Chang, K.J. and Lee, H.B. (2000). Rutin content in food products processed from groats, leaves, and flowers of buckwheat. Fagopyrum, 17:63-66.

Paulickova, I. (2008). Rutin an effective component of functional foods. Food Research Institute Prague, pp:1-7.

Pomeranz, Y.; Marshall, H. G.; Robbins, G. S. and Gilbertson, J .T. (1975) Protein content and aminoacid composition of maturing buckwheat (Fagopyrum esculentum Moench). Cereal Chemistry, 52:479-484. ISSN: 0009-0352.

Prakash, S. and Yadav, K. (2016). Buckwheat (Fagopyrum esculentum) as a functional food: A nutraceutical pseudocereal. International Journal of Current Trends in Pharmacobiology and Medical Science, 1:1-15.

Préstamo, G.; Pedrazuela, A.; Peňas, E.; Lasunción, M.A. and Arroyo, G. (2003) Role of buckwheat diet on rats as prebiotic and healthy food. Nutrition Research, 23:803-814.

Przybylski, R. and Gruczynska, E. (2009). A review of nutritional and nutraceutical components of buckwheat. The European Journal of Plant science and Biotechnology, 3(1):10-22.

Pullaiah, T. (2006). Encyclopaedia of world medicinal plants. Regency Publications New Delhi, 2:936-937.

Qin, P.; Wang, Q.; Shan, F.; Hou, Z. and Ren, G. (2010). Nutritional composition and flavonoids content of flour from different buckwheat cultivars. International Journal of Food Science and Technology, 45:951-958

Radics, L. and Mikohazi, D. (2010). Principles of common buckwhea production. European Journal of Plant Science and Biotechnology, 4:57-63.

Rana, J. C.; Chauhan, R. S.; Sharma, T. R. and Gupta, N. (2012). Analyzing problems and prospects of buckwheat cultivation in India. European Journal of Plant Science and Biotechnology, 6:50-56.

Ren, W.; Qiao, Z.; Wang, H.; Zhu, L.; Zhang, L.; Lu, Y.; Zhang, Z. and Wang, Z. (2003). Molecular basis of fas and cytochrome c pathways of apoptosis induced by tartary buckwheat flavonoid in Hl-60 cells. Methods and findings in experimental and Clinical Pharmacology, 25:431-436.

Shahidi, F. and Wanasundara, P.K.J.P.D. (1992). Phenolic antioxidants Critical Reviews in Food Science and Nutrition, 32:67-103.
Skrabanja, V. and Kreft, I. (1998). Resistant starch formation following autoclaving of buckwheat (Fagopyrum Esculentum Moench) groats: An in vitro study. Journal of Agricultural and Food Chemistry, 46:2020-2023.

Śmietana, Z.; Fornal, L.; Szpendowski, J.; Soral Śmietana, M. and Fornal, J. (1988). Utilization of milk proteins and cereal starches to obtain co-extrudates. Nahrung, 32:545-551.

Smith H.L. (1909). Buckwheat poisoning with report of a case in man. Archives of Internal Medicine, 3:350-359.

Soral-Śmietana, M. (1984). Buckwheat grain proteins. Posteppy Nauk Rolniczych, 3:35-46.

Steadman, K.J.; Burgoon, M.S.; Lewis, B.A.; Edwardson, S.E.; Obendorf, R.L. (2001b). Minerals, phytic acid, tannin and rutin in buckwheat seed milling fractions. Journal of the Science of Food and Agriculture, 81:1094-1100.

Steadman, K.J.; Burgoon, M.S.; Lewis, B.A.; Edwardson, S.E. and Obendorf, R.L. (2001a). Buckwheat seed milling fractions: description, macronutrient composition and dietary fibre. Journal of Cereal Science, 33:271-278.

Stempińska, K.; Soral-Śmietana, M.; Zieliński, H. and Michalska, A. (2007). Effect of thermal treatment on chemical and antioxidant properties of buckwheat grains. Żywność Nauka Technologia Jakość, 14:64-74.

Sugiyama, K.; Kushima, Y.D. and Muramatu, K. (1985). Effects of sulfurcontaining amino acids and glycine on plasma cholesterol diet. Agricultural and Biological Chemistry, 49:3455-3461.

Sun, T. and Ho, C. T. (2005). Antioxidant activities of buckwheat extracts. Food Chemistry, 90:743-749.

Tahir, I. and Farooq, S. (1985). Grain composition in some buckwheat cultivars (Fagopyrum spp.) with particular reference to protein fractions. Plant Foods for Human Nutrition, 35:153-158

Takahama, U. and Hirota, S. (2010). Fatty acids, epicatechindimethylgallate, and rutin interact with buckwheat starch inhibiting its digestion by amylase: Implications for the decrease in glycemic index by buckwheat flour. Journal of Agricultural and Food Chemistry, 58:12431-12439.

Tang, C.; Peng, J.; Zhen, D. and Chen, Z. (2009). Physicochemical and antioxidant properties of buckwheat (Fagopyrum esculentum Moench) protein hydrolysates. Food Chemistry, 115:672-678.

Tian, Q.; Li, D. and Patil, B. S. (2002). Identification and determination of flavonoids in buckwheat (Fagopyrum Esculentum Moench, Polygonaceae) by high-performance liquid chromatography with electrospray ionisation mass spectrometry and photodiode array ultraviolet detection. Phytochemical Analysis, 13:251-256.

Tohgi, K.; Kohno, K.; Takahashi, H.; Matsuo, H.; Nakayama, S. and Morita, E. (2011). Usability of Fag e 2 Immuno CAP in the diagnosis of buckwheat allergy. Archives of Dermatological Research, 303:635-642.

Tomotake, H.; Shimaoka, I.; Kayashita, J.; Nakajoh, M. and Kato, N. (2002). Physicochemical and functional properties of buckwheat protein product. Journal of Agricultural and Food Chemistry, 50:2125-2129.

Tomotake, H.; Shimaoka, I.; Kayashita, J.; Yokoyama, F.; Nakajoh, M. and Kato, N. (2000). A buckwheat protein product suppresses gallstone formation and plasma cholesterol more strongly than soy protein isolate in hamsters. Journal of Nutrition, 130:1670-1674.

Tomotake, H.; Shimaoka, I.; Kayashita, J.; Yokoyama, F.; Nakajoh, M. and Kato, N. (2001). Stronger suppression of plasma cholesterol and enhancement of the fecal excretion of steroids by a buckwheat protein product than by a soy protein isolate in rats on a cholesterol free diet. Bioscience, Biotechnology and Biochemistry, 65:1412-1414. 
Tomotake, H.; Yamamoto, N.; Yanaka, N.; Ohinata, H.; Yamazaki, R.; Kayashita, J. and Kato N. (2006). High protein flour suppresses hypercholesterolemia in rats and gallstone formation in mice by hypercholesterolemic diet and body fat in rats because of its low protein digestibility. Nutrition, 22:166-173.

Tuan, P. A.; Thwe, A. A.; Kim, J. K.; Kim, Y. B.; Lee, S.; Park S. U. (2013). Molecular characterisation and the light-dark regulation of carotenoid biosynthesis in sprouts of tartary buckwheat (Fagopyrum tataricum Gaertn). Food Chemistry, 141:3803-3812.

Van Hung, P. and Morita, N. (2008). Distribution of phenolic compounds in the graded flours milled from whole buckwheat grains and their antioxidant capacities. Food chemistry, 109:325-331.

Verardo, V.; Arraez-Roman, D.; Segura-Carretero, A.; Marconi, E.; FernandezGutierrez, A. and Caboni, M. F. (2011). Determination of free and bound phenolic compounds in buckwheat spaghetti by RP-HPLC-ESITOFMS: effect of thermal processing from farm to fork. Journal of Agricultural and Food Chemistry, 59:7700-7707.

Verma, K.C. (2018). Biochemical constituents of buckwheat (Fagopyrum esculentum Moench) collected from different geographical regions of Himachal Pradesh. Molecular Biology Reports, 45:2681-2687.

Vombergar, B.; Vida, Š. and Mateja, G. (2020). Flavonoid concentration in milling fractions of tartary and common buckwheat. Fagopyrum, 37(1):11-21.

Watanabe, M. (1998). Catechins as antioxidants from buckwheat (Fagopyrum Esculentum Moench) groats. Journal of Agricultural and Food Chemistry, 46:839-845.

Wei, Y.; Hu, X.; Zhang, G. and Ouyang, S. (2003). Studies on the amino acid and mineral content of buckwheat protein fractions. Nahrung/ Food, 47:114-116.
Wijngaard H.H. and Arendt, E.K. (2006). Buckwheat. Cereal Chemistry, 83:391-401.

Ya-ping, Y.; Cheng-rui, T. and Wei, C. (2008). Anti-oxidative constituents of ethanol extract from buckwheat seeds by HPLC-ElectroSpray MS. Agricultural Sciences in China, 7:356-362.

Yildizog`Lu-Ari, N.; Altan, V. M.; Altinkurt, O. and Öztürk, Y. (1991). Pharmacological effects of rutin. Phytotherapy Research, 5:19-23.

Youssef, M. K. E.; Nassar, A. G.; EL-Fishawy, F. A. and Mostafa, M. A. (2016). Assessment of proximate chemical composition and nutritional status of wheat biscuits fortified with oat powder. Assiut Journal of Agricultural Sciences, 47:83-94.

Zdunczyk, Z.; Flis, M.; Zielinski, H.; Wroblewska, M.; Antoszkiewicz, Z. and Juskiewicz, J. (2006). In vitro antioxidant activities of barley, husked oat, naked oat, triticale, and buckwheat wastes and their influence on the growth and biomarkers of antioxidant status in rats. Journal of Agricultural and Food Chemistry, 54:4168-4175.

Zhang, Z.; He, C.; Zhu1, R.; Shen, J.; Yu, Y.; Qiang, P.; Gao, J.; Li, Y. and Wang, M. (2016). Seed oils of five black tartary buckwheat cultivars with biochemical characterization and antioxidant properties. Journal of the American Oil Chemists' Society, 93:1127-1136.

Zhao, G., Tang, Y., Ma, R.; Hu., Z. (2001). Nutritional and medicinal values of tartary buckwheat and its development and application. The proceeding of the 8 "'ISB, pp:503-506.

Zhou, X.; Hao, T.; Zhou, Y.; Tang, W.; Xiao, Y.; Meng, X.; Fang, X. (2015). Relationships between antioxidant compounds and antioxidant activities of tartary buckwheat during germination. Journal of Food Science and Technology, 52(4):2458-2463.

Citation Kuldip Chandra Verma, Amit Singh Rana, Nidhi Joshi and Dheeraj Bhatt (2020). Review on common buckwheat (Fagopyrum esculentum Moench): A potent Himalayan crop. Ann. Phytomed., 9(2):125-133. http://dx.doi.org/10.21276/ ap.2020.9.2.10 